\title{
Plasmopara invertifolia sp. nov. causing downy mildew on Helichrysum bracteatum (Asteraceae)
}

\author{
Lidiane L. Duarte • Young-Joon Choi • \\ Dartanhã J. Soares • Robert W. Barreto
}

Received: 11 April 2013 /Revised: 2 July 2013 / Accepted: 9 July 2013 / Published online: 27 July 2013

(C) German Mycological Society and Springer-Verlag Berlin Heidelberg 2013

\begin{abstract}
Plasmopara invertifolia sp. nov. causes severe leaf distortion and necrosis on Helichrysum bracteatum, a beautiful and important ornamental plant for trade in Brazil. This oomycete pathogen is distinguished from other species of Plasmopara on Asteraceae by its smaller sporangia and larger sporangiophores, which justifies the proposition of a new taxon in the genus Plasmopara to accommodate it. The phylogenetic analysis of cox 2 gene sequence data supports such placement and also shows that $P$. invertifolia is close to the $P$. halstedii complex. Plasmopara invertifolia is then described, illustrated and discussed.
\end{abstract}

Keywords Molecular phylogeny · Oomycetes · Ornamental plant $\cdot$ Peronosporales $\cdot$ Plant pathology $\cdot$ Strawflower

\section{Introduction}

Helichrysum bracteatum (Vent.) Andrews (Asteraceae), popularly known as strawflower, everlasting or eternal flower (in Brazil, sempre-viva and flor de palha), is an annual plant native to Australia, known worldwide by the beauty

\footnotetext{
L. L. Duarte $\cdot$ R. W. Barreto $(\bowtie)$

Departamento de Fitopatologia, Universidade Federal de Viçosa, 36570-000 Viçosa, MG, Brazil

e-mail: rbarreto@ufv.br

Y.-J. Choi

Biodiversity and Climate Research Centre (BiK-F),

Senckenberganlage 25, 60325 Frankfurt (Main), Germany

Y.-J. Choi

Department of Biological Sciences, Institute of Ecology, Evolution and Diversity, Goethe University, Siesmayerstr. 70,

60323 Frankfurt (Main), Germany

D. J. Soares

Embrapa Algodão, 58428-095 Campina Grande, PB, Brazil
}

and durability of its flowers and widely cultivated as an ornamental garden plant or for the cut flower industry (Morley 1978; Lorenzi and Souza 2001). Although diseases are known by gardeners in Brazil to be a limiting factor for its cultivation there was no published record of diseases on this host until recently, when stem rot caused by Sclerotinia sclerotiorum (Lib.) de Bary was first reported (Duarte and Barreto 2009). Everlasting is not an exception in terms of lack of knowledge about its mycobiota. Although of economic relevance and scientific interest such fungal pathogens have often been overlooked by plant pathologists in Brazil who have tended to concentrate on major crop plants.

In 2008, diseased individuals of $H$. bracteatum bearing typical downy mildew symptoms were observed in a small teaching and research area in the campus of the Universidade Federal de Viçosa (Viçosa, State of Minas Gerais, Brazil). Considering the scarcity of information about fungi in association with this host plant in Brazil, a study was initiated aimed at elucidating the etiology of this disease. This publication includes a description of the downy mildew pathogen found on everlasting in Brazil and the proposal of a new species to accommodate it.

\section{Material and methods}

Leaf samples of $H$. bracteatum bearing disease symptoms and sporulation of a pathogen were collected at the site of occurrence, dried in a plant press, and deposited in the local herbarium (Herbarium VIC). All samples were examined under a dissecting microscope, and wherever pathogen structures appeared to be associated with the disease symptoms, slides containing scraped fungal structures or free hands sections were prepared using lactophenol or lactofuchsin as mounting medium. Observations of fungal structures, as well as measurements and photographs were made with an Olympus BX 51light microscope fitted with an Olympus E330 camera 
(Olympus, Tokyo, Japan). All the structures were measured at least 80 times.

Additionally, total genomic DNA was isolated from the leaves samples using the Wizard ${ }^{\circledR}$ Genomic DNA Purification Kit (Promega Corporation, WI, USA) according to the manufacturer's instructions. Part of the cytochrome c oxidase subunit 2 (cox2) was amplified using the peronosporomycetes-specific primer set designed in Hudspeth et al. (2000). The $25 \mu \mathrm{L}$ PCR reaction consisted of the $2 \mu \mathrm{L}(20 \mathrm{ng})$ of DNA, $12.5 \mu \mathrm{L}$ of the Dream Taq Master Mix (Fermentas Company) and $10 \mu \mathrm{M}$ of each primer. The PCR was performed as described by Hudspeth et al. (2000). The nucleotide sequence data were obtained by DNA sequencing (Macrogen Inc., South Korea) employing the same primers used for PCR amplification. The sequence fragments were assembled from the forward and reverse sequences with the help of DNA Dragon program v 1.1.9.1. For comparison to other Plasmopara species, 18 cox2 mtDNA sequences used in previous studies of Göker et al. (2007), Choi et al. (2009), Schröder et al. (2011) and Thines (2011) were retrieved from GenBank. Alignment of the sequences was performed using CLUSTAL X (Thompson et al. 1997), which is feasible as the alignment contains no gap. Phylogenetic analyses were done on the resulting alignment using Maximum Evolution (ME) and Maximum Likelihood (ML) methods. ME analysis was done using MEGA 5.0 (Tamura et al. 2011), with the default settings of the program, except for using the TamuraNei model instead of the maximum composite likelihood model. The strength of the internal branches from the resulting trees was tested by bootstrap analysis using 1,000 replications. For ML analyses, 1,000 rounds of random addition of sequences as well as 1,000 fast bootstrap replicates were computed with RAxML 7.0.3 (Stamatakis 2006) as implemented in raxmlGUI 1.3 (Silvestro and Michalak 2012) using the GTRCAT variant.

\section{Results}

Phylogenetic analysis

The phylogenetic relationship among Plasmopara species was inferred from the ME and ML analyses of partial cox2 mtDNA sequences. Since no differences were found between the tree topologies of the ME and ML analyses, only the ME tree is shown in Fig. 1, with the addition of the bootstrap support values of the ML analysis. In the phylogenetic tree, Plasmopara sp. on Helichrysum occupied a separate branch within the genus Plasmopara. The sequence distances to the $P$. halstedii complex were considerable as $9.8 \%$ (46 of 505 nucleotides characters were different) to $P$.

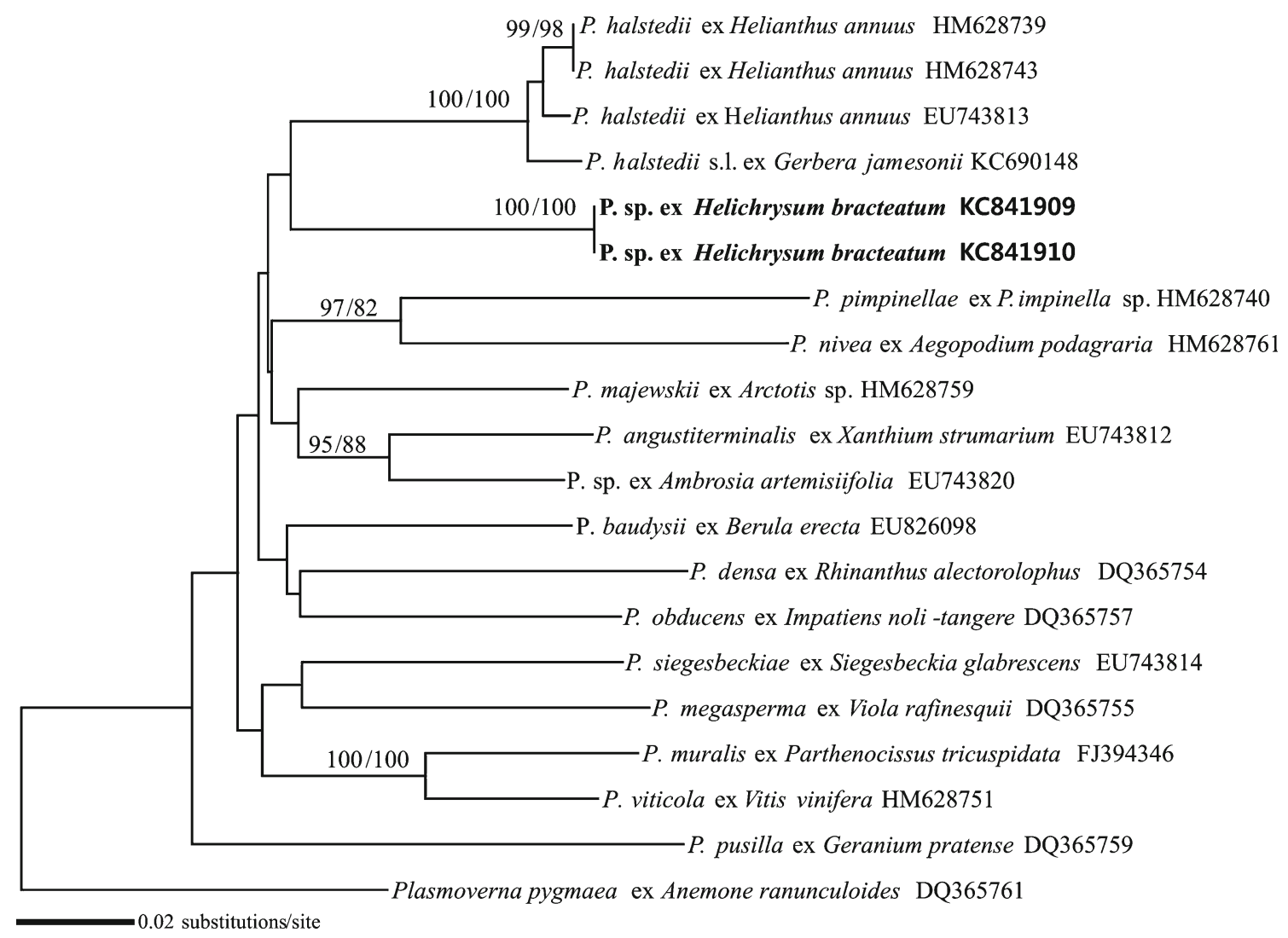

Fig. 1 Maximum evolution tree inferred from partial cox 2 sequence matrix. ME and ML bootstrap supports above $60 \%$ are given at first and second position, respectively, above the branches 
halstedii in Europe (HM628739 \& HM628743), 10.5 \% (49 of 505 nucleotides) to P. halstedii in East Asia (EU743813), and $11.3 \%$ (52 of 505 nucleotide) to P. halstedii s.l. on Gerbera jasmonii (GenBank no. KC690148).

\section{Taxonomy}

Plasmopara invertifolia L.L Duarte \& R. W Barreto sp. nov. Mycobank no.: MB 803920 (Fig. 2).

Etymology - Referring to the tendency of the fungal infection to invert the leaves

Type: Brazil, Minas Gerais, Viçosa, on leaves of Helichrysum bracteatum, collected by Robert W. Barreto in 15 September 2009, VIC 32069. Sequences ex-type: KC841909 (cox2 mtDNA).

Description: Lesions on living leaves, irregular, initially appearing as ill-delimited yellowed area and becoming yellowish adaxially and finally necrotic leading to blight of large parts or entire leaves; abaxially a sparse to dense layer of downy whitish sporulation formed on the lower leaf side of infected areas; often causing to lamina and petiole distortion resulting in overturned leaves and appearing like spoons, containing sporangia and sporangiophores. External mycelium absent. Internal mycelium and haustoria not visible. Sporangiophores hypophyllous, emerging through stomata, cylindrical, straight, up to $670 \mu \mathrm{m}$ long, $7.5-12 \mu \mathrm{m}$ diameter, with slightly swollen base 8 to $13.5 \mu \mathrm{m}$ wide, hyaline, aseptate, with up to 6 monopodial ramifications, mainly at right angles; ultimate branchlet straight to slightly curved, $7-13.5 \mu \mathrm{m}$ long, 2-4 $\mu \mathrm{m}$ wide at the base; tips truncate and with 2 or 3 sterigmata; sporangia hyaline, globose to ovoid, tip and base round, smooth, 9-20×9-18 $\mu \mathrm{m}$, non-papillate or with a slight papilla, pedicel absent. Resting organs not observed.

\section{Discussion}

Three different genera of Peronosporaceae, Bremia, Paraperonospora, and Plasmopara, have been reported to cause downy mildew disease on $H$. bracteatum. The morphology of the asexual structures of the present pathogen is typical of the genus Plasmopara. The genus Bremia, known previously from $H$. bracteatum, is easily distinguishable from the present pathogen by mostly dichotomous branching pattern of the conidiophores and the shape of the tip of the ultimate branchlets (Choi et al. 2011). The other Plasmopara species described on $H$. bracteatum, Plasmopara helichrysi, was combined under Paraperonospora (Tao 1991). This genus also clearly differs from Plasmopara by conidiophores that branch differently in obtuse angles as opposed to right angles in the latter genus.

Initially the newly collected pathogen was considered to represent Plasmopara halstedii (Farl.) Berl. \& De Toni, a

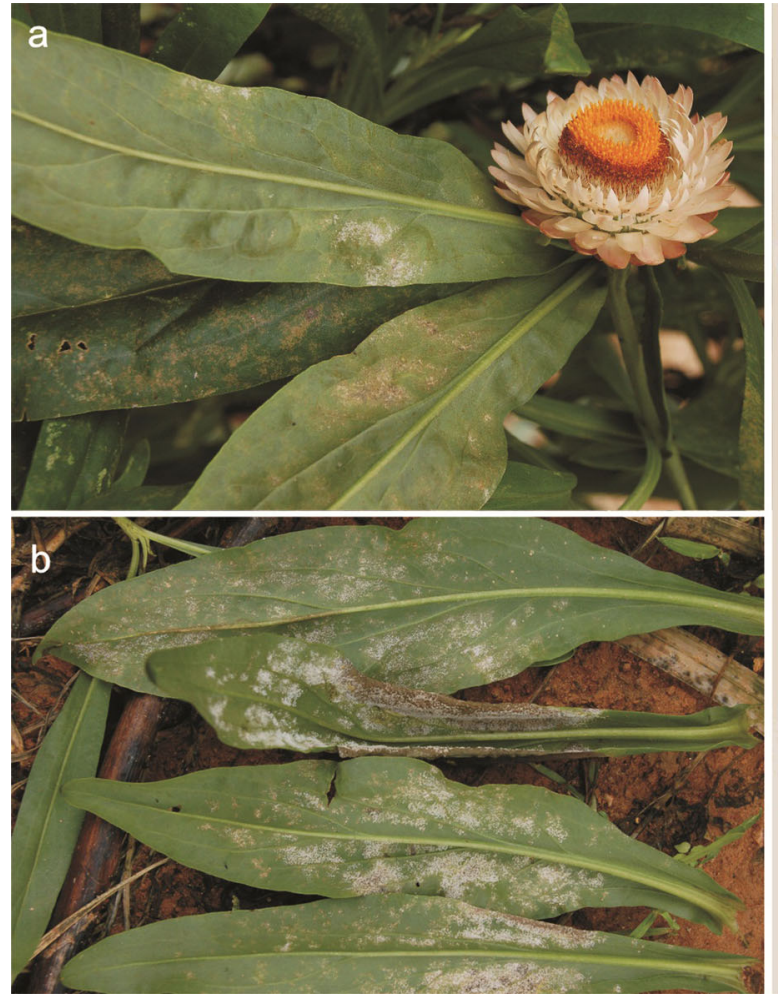

Fig. 2 Plasmopara invertifolia on H. bracteatum. a, b Downy mildew symptoms on leaves (note in $\mathbf{b}$ a leaf with advanced blight due to infection by $P$. invertifolia). c Sporangiophore with young sporangia

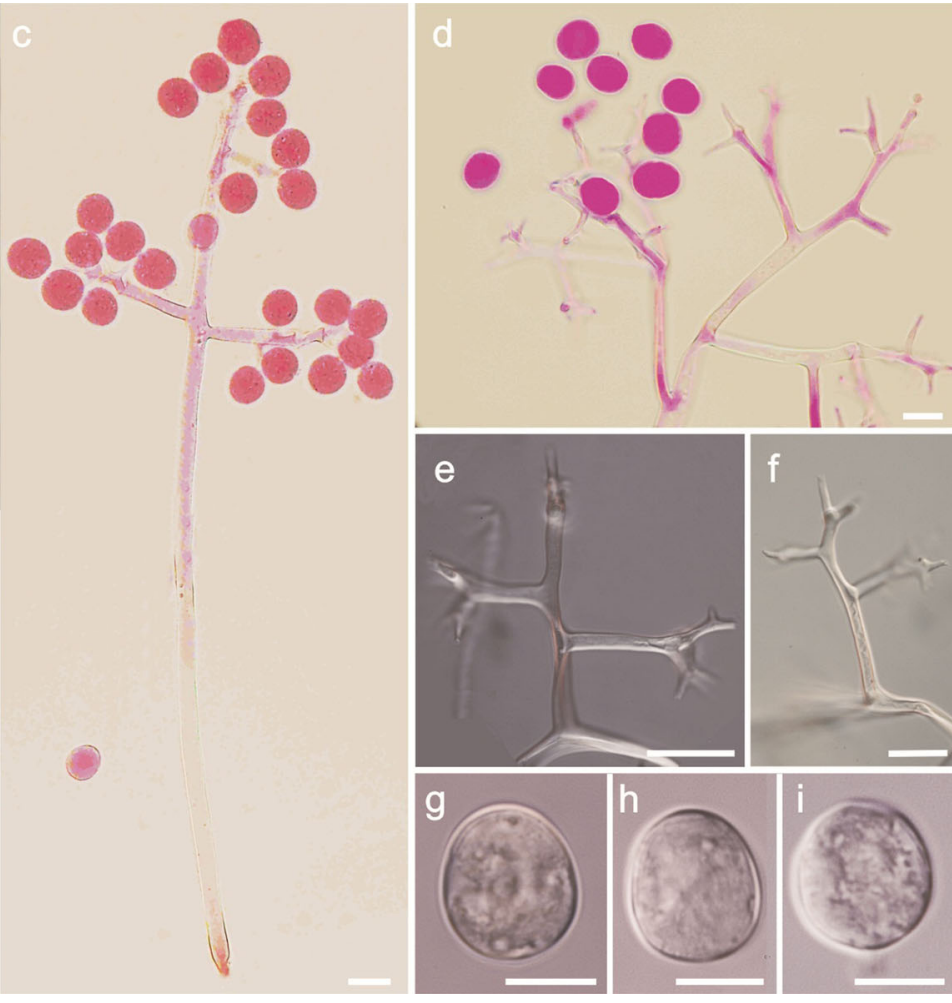

still attached. d Close-up of sporangiophore apex showing branching pattern ( $\mathbf{c}$ and $\mathbf{d}$ mounted in lactofuchsin). e, $\mathbf{f}$ Branches. $\mathbf{g}-\mathbf{i}$ Sporangia. Scale bars $=10 \mu \mathrm{m}$ 


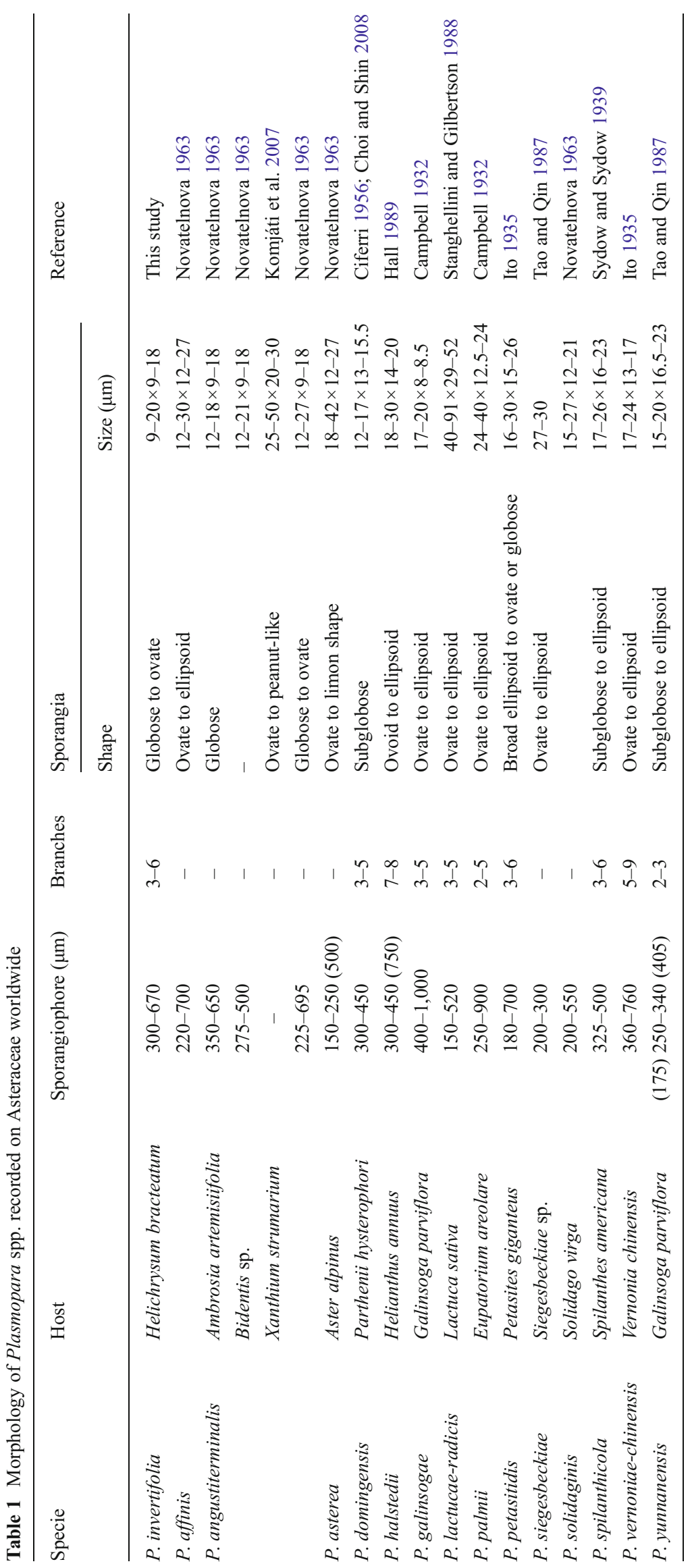


common species having a relatively broad host-range in the Asteraceae with a worldwide distribution excluding Australia and New Zealand (Hall 1989; Constantinescu and Thines 2010) and which has been already reported on $H$. bracteatum (Farr et al. 2013). Nevertheless, after a closer examination it became clear that the fungus collected in Brazil did not fit into P. halstedii. Plasmopara invertifolia has smaller sporangia than those of $P$. halstedii; it also has longer sporangiophores and its sporangia are of a different shape (Table 1). Sporangia in Plasmopara invertifolia are, as well, of a distinct size as compared with other species in this genus described on Asteraceae (Table 1). The exception is P. angustiterminalis which sporangia are only slightly bigger (Table 1).

Species in Plasmopara are usually regarded to be host specific and that, with the exception of $P$. halstedii hostspecialization is also considered to be relevant for species distinction. Only $P$. halstedii has been reported on $H$. bracteatum and it is clearly morphologically distinct from the newly collected fungus and this is regarded here as additional evidence that a new species of Plasmopara is involved. Finally, the phylogenetic analysis also supports that $P$. invertifolia is a taxon distinct from $P$. halstedii and $P$. angustiterminalis (Fig. 1) with an independent position in the Plasmopara.

Although this was not investigated in detail, our observations of the tendency of the infection to lead to a distortion of the leaves, completely exposing the fungus colony, allows of a conjecture that this might represent an adaptation of the $P$. invertifolia favoring its dispersal by direct hit of rain drops, the wind and even a catapult effect. As H. bracteatum is not indigenous to Brazil, it is possible that this pathogen was originally introduced into Brazil from its native range in Australia together with its host and that earlier reports of Plasmopara on H. bracteatum actually represent $P$. invertifolia .

Acknowledgments Financial support by the Coordenação de Aperfeiçoamento de Pessoal de Nível Superior (CAPES) to who LLD and RWB is gratefully acknowledged. YJC appreciates support by the Alexandervon-Humboldt Foundation.

\section{References}

Campbell L (1932) Some species of Plasmopara on composites from Guatemala. Mycologia 24:330-333

Ciferri R (1956) Mycoflora domingensis exsiccata. Sydowia 10(6):130180

Choi YJ, Kiss L, Vajna L, Shin HD (2009) Characterization of a Plasmopara species on Ambrosia artemisiifolia, and notes on P. halstedii, based on morphology and multiple gene phylogenies. Mycol Res 113:11271136
Choi YJ, Shin HD (2008) Reclassification of Bremia domingensis to the genus Plasmopara as $P$. domingensis comb. nov. Mycotaxon 105:191-194

Choi YJ, Thines M, Runge F, Hong SB, Telle S, Shin HD (2011) Evidence for high degrees of specialisation, evolutionary diversity, and morphological distinctiveness in the genus Bremia. Fungal Biol 115:102-111

Constantinescu O, Thines M (2010) Plasmopara halstedii is absent from Australia and New Zealand. Pol Bot J55:293-298

Duarte LL, Barreto RW (2009) First report of stem rot of Helichrysum bracteatum by Sclerotinia sclerotiorum in Brazil. Austral Plant Dis Notes 4:100-101

Farr DF, Rossman AY, Palm ME, McCray EB (2013) Fungal databases, systematic botany and mycology laboratory, ARS, USDA. http:// nt.ars-grin.gov/fungaldatabases/ Accessed 15 January 2013

Göker M, Voglmayr H, Riethmüller A, Oberwinkler F (2007) How do obligate parasites evolve? A multi-gene phylogenetic analysis of downy mildews. Fungal Genet Biol 44:105-122

Hall G (1989) Plasmopara halstedii. CMI Descriptions of Fungi and Bacteria No 979. Mycopathologia 106:205-207

Hudspeth DSS, Nadler SA, Hudspeth MES (2000) A COX2 molecular phylogeny of the Peronosporomycetes. Mycologia 92:674-684

Ito A (1935) Notae mycologicae asiae orientalis I. Trans Sapporo Nat Hist Soc 14:11-33

Komjáti H, Walcz I, Virányi F, Zipper R, Thines M, Spring O (2007) Characteristics of a Plasmopara angustiterminalis isolate from Xanthium strumarium. Eur J Plant Pathol 119:421-428

Lorenzi H, Souza HM (2001) Plantas ornamentais no Brasil: arbustivas, herbáceas e trepadeiras. Instituto Plantarum, Nova Odessa

Morley B (1978) Helichrysum bracteatum and allies. Garden 103:489491

Novatelnova NS (1963) Species novae generis Plasmoparae ad Compositas. Bot Mat 16:73-83

Schröder S, Telle S, Nick P, Thines M (2011) Cryptic diversity of Plasmopara viticola (Oomycota, Peronosporaceae) in North America. Org Divers Evol 11(1):3-7

Silvestro D, Michalak I (2012) raxmlGUI: a graphical front-end for RAxML. Org Divers Evol 12(4):335-337

Stamatakis A (2006) RAxML-VI-HPC: maximum likelihood-based phylogenetic analyses with thousands of taxa and mixed models. Bioinformatics 22:2688-2690

Stanghellini ME, Gilbertson RL (1988) Plasmopara lactucae-radicis, a new species on roots of hydroponically grown lettuce. Mycotaxon 21(2):395-400

Sydow H, Sydow P (1939) Fungi aequatoriensis. Ann Mycol 37:275438

Tamura K, Peterson D, Peterson N, Stecher G, Nei M, Kumar S (2011) MEGA5: molecular evolutionary genetics analysis using maximum likelihood, evolutionary distance, and maximum parsimony methods. Mol Biol Evol 28(10):2731-2739

Tao J (1991) Recognition of the genus Paraperonospora and the species from China. J Yunnan Agric Univ 6:129-135

Tao JF, Qin Y (1987) Taxonomic studies on the genus Plasmopara of China III. New species, new combination and new record Plasmopara on family Compositae. Acta Mycol Sin 6:65-73

Thines M (2011) Recent outbreaks of downy mildew on grape ivy (Parthenocissus tricuspitada, Vitaceae) in Germany are caused by a new species of Plasmopara. Mycol Progress 10:415-422

Thompson JD, Gibson TJ, Plewniak F, Jeanmougin F, Higgins DG (1997) The CLUSTAL_X windows interface: flexible strategies for multiple sequence alignment aided by quality analysis tools. Nucleic Acids Res 25(24):4876-4882 